\title{
PENGARUH CR, DER, ROA, DAN PER TERHADAP HARGA SAHAM PADA PERUSAHAAN FARMASI DI BEI
}

\author{
Indah Sulistya Dwi Lestari ${ }^{1}$ \\ Ni Putu Santi Suryantini ${ }^{2}$
}

\author{
${ }^{1,2}$ Fakultas Ekonomi dan Bisnis UniversitasUUdayana (Unud), Bali, Indonesia \\ e-mail: indahsulistyaa6@yahoo.co.id
}

\begin{abstract}
ABSTRAK
Penelitian ini bertujuan untuk melihat stabilitas harga saham disebuah perusahaan Pharmacy yang terdapat dalam Bursa Efek Indonesia (BEI) periode tahun 2014 - 2016 dengan menggunakan beberapa variabel seperti CR, DER, ROA dan PER. Penelitian kali ini termasuk jenis penelitian kuantitatif dengan menggunakan analisis fundamental yang mengacu pada analisis terhadap kinerja perusahaan yang digunakan untuk memprediksi harga saham di masa yang akan datang. Metode penentuan sampel pada penelitian ini didasarkan pada teknik purposive sampling yang sudah sesuai dengan krtiteria dari delapan perusahaan farmasi. Data yang digunakan dalam penelitian ini dikumpulkan melalui metode observasi non partisipan dengan menggunakan data yang terdapat dalam BEI. Pengujian terhadap hipotesis pada penelitian ini menggunakan analisis regresi linier berganda. Hasil penelitian memperlihatkan bahwa tidak adanya pengaruh yang signifikan terhadap harga saham apabila menggunakan CR, DER, ROA dan PER. Sebaliknya, PER berpengaruh signifikan terhadap harga saham perusahaan farmasi periode tahun 2014-2016.
\end{abstract}

Kata Kunci: analisis fundamental, current ratio, debt to equity ratio, return on asset, price earning ratio, harga saham

\begin{abstract}
This study aims to see stock price stability at a Pharmacy company listed on the Indonesia Stock Exchange (IDX) for the period 2014 - 2016 by using several variables such as Current Ratio, Debt to Equity Ratio, Return on Assets and Price Earning Ratio. This research is a type of quantitative research which used fundamental analysist by referring to an analysis of company performance that is used to predict stock prices in the future. The method of determining the sample in this study is based on purposive sampling technique that is in accordance with the criteria of eight pharmacy companies. The data used in this study were collected through non-participant observation methods using the data contained in the IDX. Testing of the hypothesis in this study using multiple linear regression analysis. The test results show that there is no significant influence on stock prices when using Current Ratio, Debt to Equity Ratio, Return on Assets and Price Earning Ration. On the contrary, Price Earning Ration partially has a positive and significant effect on the stock price of pharmaceutical companies in the 2014-2016 period.
\end{abstract}

Keywords: fundamental analysis, current ratio, debt to equity ratio, return on asset, price earning ratio, stock price 


\section{PENDAHULUAN}

Saham dapat didefinisikan sebagai tanda penyertaan atau kepemilikan seseorang atau badan atas suatu perusahaan atau perseroan terbatas. Menurut Brigham and Houston (2010), saham juga dapat diartikan sebagai tanda bukti pengambilan bagian dalam suatu perseroan terbatas Wujud saham adalah selembar kertas yang menerangkan bahwa pemilik kertas tersebut adalah pemilik perusahaan yang menerbitkan surat berharga tersebut. Porsi kepemilikan ditentukan oleh seberapa besar penyertaan yang ditanamkan di perusahaan tersebut (Darmadji dan Fakhruddin, 2008). Bagi calon investor yang rasional, keputusan investasi dalam suatu saham harus didahului oleh suatu proses analisis. Analisis ini dilakukan untuk melihat adanya variabel yang diperkirakan akan mempengaruhi harga suatu saham nantinya. Hal ini dikarenakan sifat saham yang sangat peka terhadap perubahanperubahan yang terjadi baik dalam suatu perubahan kondisi pasar uang, kinerja keuangan maupun situasi politik dalam negeri. Perubahan-perubahan dalam aspek tersebut menjadi salah satu penyebab dari adanya proses analisis suatu variable dalam keputusan investasi.

Keputusan investasi juga dipengaruhi oleh harga saham. Harga saham sendiri dapat didefinisikan sebagai uang yang dikeluarkan untuk memperoleh bukti penyertaan atau pemilikan suatu perusahaan Kuswara (2012). Harga saham kemudian menjadi salah satu indikator keberhasilan pengelolaan perusahaan. Jika harga saham suatu perusahaan selalu mengalami kenaikan, maka investor atau calon investor dapat menilai bahwa perusahaan telah berhasil dalam mengelola usahanya sendiri. Harga saham juga dipengaruhi oleh kinerja perusahaan, apabila 
kinerja perusahaan baik maka nilai perusahaan akan tinggi. Semakin tinggi harga saham suatu perusahaan, maka semakin tinggi pula nilai perusahan tersebut dan begitu sebaliknya. Harga saham yang terlalu rendah, dapat diartikan bahwa kinerja suatu perusahaan tersebut sedang tidak baik. Praditasari (2012) juga menyatakan bahwa apabila suatu perusahaan memiliki nilai yang tinggi maka, para investor akan melirik perusahaan tersebut untuk menanamkan modalnya. Tindakan investor akan mempengaruhi kemungkinan adanya kenaikan harga saham perusahaan tersebut. Pernyataan tersebut juga didukung oleh Kuswara (2012) yang menyatakan bahwa ide dasar dari pendekatan diatas adalah bahwa harga saham disuatu perusahaan nantinya akan dipengaruhi oleh kinerja perusahaan itu sendiri.

Suatu perusahaan yang akan mengiventasikan sahamnya, tentunya memiliki tujuan - tujuan tertentu. Salah satu tujuan dari investasi saham adalah untuk mendapatkan capital gain dan dividen (Hermuningsih, 2012). Capital gain secara harafiah dapat didefinisikan sebagai keuntungan dalam bentuk uang yang diperoleh dari penjualan property atau dari sebuah investasi. Capital gain dapat juga dikatakan sebagai selisih lebih antara harga beli dengan harga jual saham. Dividen sendiri kemudian dapat diartikan sebagai keuntungan perusahaan yang dibagikan kepada para pemegang saham. Brigham and Houston (2010) menyatakan bahwa sudah sewajarnya jika investor mengharapkan return yang tinggi dari investasi yang dilakukannya.

Beberapa penelitian telah dilakukan untuk memperoleh pengaruh rasio keuangan terhadap harga saham. Penelitian dilakukan oleh Dian (2013) yang menguji pengaruh Current Ratio (CR) dan Total Asset Turnover (TATO) terhadap 
harga saham di BEI dengan hasil penelitian bahwa variabel CR tidak berpengaruh signifikan terhadap harga saham, sedangkan variabel TATO memiliki pengaruh yang positif signifikan terhadap harga saham. Penelitian berikutnya dilakukan oleh Maria (2014) yang menguji pengaruh Total Asset Turnover (TATO) dan Return on Asset (ROA) terhadap harga saham di BEI dengan hasil penelitian bahwa variabel TATO dan ROA sama-sama memiliki pengaruh positif signifikan terhadap harga saham. Penelitian juga pernah dilakukan oleh Isti (2017) yang menguji pengaruh variabel Return on Investment (ROI), Return on Equity (ROE), Total Asset Turnover (TATO), dan Price Earning Ratio (PER) terhadap harga saham di BEI dengan hasil penelitian bahwa variabel PER berpengaruh tidak signifikan terhadap harga saham, sedangkan ROI, ROE, dan TATO memiliki pengaruh positif signifikan terhadap harga saham. Penelitian yang terakhir dilakukan oleh Eddy (2016) yang menguji pengaruh Current Ratio (CR), Return on Equity (ROE), Debt to Equity Ratio (DER), Earning Per Share (EPS), dan Total Asset Turnover (TATO) terhadap harga saham di BEI dengan hasil penelitian bahwa variabel CR, ROE, dan TATO berpengaruh positif signifikan terhadap harga saham, sedangkan variabel DER dan EPS tidak berpengaruh terhadap harga saham.

Dari beberapa hasil penelitian di atas terlihat bahwa rasio aktivitas yaitu Total Asset Turnover (TATO) memiliki hasil yang sama disetiap penelitian, maka rasio keuangan ini tidak dimasukan di dalam penelitian ini. Berdasarkan beberapa faktor yang mempengaruhi harga saham, penelitian ini menggunakan empat variabel independen. Keempat variabel tersebut yaitu, Current Ratio, Debt to Equity Ratio, Return on Asset dan Price Earning Ratio. Penelitian ini menggunakan ke-empat 
variabel tersebut karena mengukur kinerja perusahaan, dimana kinerja perusahaan yang tinggi merupakan suatu keberhasilan perusahaan dalam memperoleh laba berdasarkan aktivanya maupun berdasarkan modal sendiri.

Rasio likuiditas adalah sebuah cara untuk mengukur kemampuan perusahaan dalam memenuhi kewajiban jangka pendeknya Wiagustini (2014). Kuswara (2012) menemukan terdapatnya pengaruh yang signifikan dari Current Ration pada nilai perusahaan Brigham, (2006:136), hal ini dapat diakbatkan karena tingginya CR perusahaan menunjukan semakin tinggi pula kapabilitas manajemen perusahaan memenuhi kewajiban perusahaan untuk membuat para stokeholder merasa lebih safe memberikan modalnya ke perusahaan tersebut hal ini dapat memberikan dampak peningkatan harga saham yang disebabkan karena CR yang tinggi.

Debt to equity ratio yang merupakan rasio yang digunakan untuk menggambarkan struktur modal perususahaan melalui pinjaman yang diberikan pada perusahaan Brigham, (2006:143). DER juga dapat digunakan untuk mengukur seberapa besar perusahaan menggunakan pendanaan yang berasal dari utang dalam permodalan (financial Debt to Equity Ratio) (Brigham, 2006:143).

Harahap (2009) menyatakan semakin tinggi DER berarti semakin tinggi pula risiko yang mungkin dihadapi perusahaan. Tingginya DER dapat mengurangi keuntungan dari perusahaan, DER merupakan perbandingan antara kewajiban perusahaan dengan modal perusahaan, relatifnya semakin tinggi DER menunjukan bahwa semakin besarnya proporsi hutang dalam modal perusahaan yang mana akan menyebabkan risiko gagal bayar yang lebih tinggi Omete (2013). DER yang tinggi mengindikasikan perusahaan harus membayar bunga yang tinggi pula. Secara 
investor lebih merasa aman dengan memilih untuk berinvestasi pada perusahaan dengan hutang yang lebih rendah (Nirmala et al.,2011). Hatta dan Dwiyanto (2012) juga menemukan hasil yang serupa yaitu terdapatnya hubungan DER yang negatif dan signifikan pada harga saham perusahaan yang terdaftar di Bursa Efek Indonesia tahun 2002-2006. Pradipta (2012) menemukan DER berpengaruh positif pada harga saham perusahaan, karena DER yang tinggi dianggap sebagai sinyal optimis yang diberikan manajemen perusahaan untuk investor.

Profitabilitas adalah rasio berguna untuk mengukur kemampuan perusahaan dalam menghasilkan keuntungan berdasarkan operasi perusahaan Wiagustini (2014), rasio ini dapat di hitung dengan ROA yang mengukur kemampuan menghasilkan laba dari total aktiva yang digunakan Wiagustini (2014). Arsita (2012) menyatakan, perusahaan selalu berupaya agar ROA dapat selalu ditingkatkan. ROA yang semakin tinggi menunjukkan semakin efektif perusahaan memanfaatkan aktivanya untuk menghasilkan laba bersih setelah pajak, dengan semakin meningkatnya ROA maka kinerja perusahaan semakin baik. Penelitian ini menggunakan ROA sebagai proksi karena ingin mengetahui pengaruh kinerja perusahaan terhadap harga saham melalui total aktiva atau total aset yang dimiliki oleh perusahaan.

Silviana dan Rocky (2013) menggunakan sampel perusahaan yang go public di Bursa Efek Indonesia menunjukan ROA memiliki pengaruh positif tidak signifikan terhadap harga saham. Haque dan Faruquee (2013) juga menemukan hasil adanya pengaruh ROA positif tidak signifikan terhadap harga saham perusahaan Pharmacy yang terdaftar di Dhaka Stock Exchange. 
Price Earning Ratio menunjukan seberapa besar para investor bersedia dibayar untuk setiap keuntungan yang dilaporkan perusahaan sehingga merupakan salah satu alat untuk mengukur kinerja perusahaan karena terdapat perbedaan hasil penelitian dalam penelitian sebelumnya tentang pengaruh Price Earning Ratio terhadap harga saham. Sanjeet (2011) menarik kesimpulan bahwa Price Earning Ratio mempunyai pengaruh positif dan tidak signifikan terhadap harga saham pada perusahaan manufaktur tahun 1993-2000 di Bursa Efek Bombay, India. Wang Junjie (2013) menyatakan bahwa Price Earning Ratio tidak berpengaruh terhadap harga saham pada obyek penelitian perusahaan non-loss yang terdaftar di Bursa Efek Shanghai, Cina. Francisca (2008) mengatakan bahwa Price Earning Ratio tidak berpengaruh signifikan terhadap return saham pada sektor LQ 45 tahun 20032006.

Penelitian ini dilakukan pada perusahaan Pharmacy karena perusahaan pada sektor ini memiliki persebaran jenis usaha yang luas serta memiliki harga saham yang stabil yang dapat membuat para investor masih menjadi pilihan investasi pada sektor manufaktur.

Teori sinyal mengatakan bahwa perusahaan memiliki kewajiban untuk memberikan informasi laporan keuangan yang sebenar-benarnya pada pihak eksternal, yaitu pemilik perusahaan atau pemilik saham perusahaan. Perwira dan Darsono (2015) menyatakan bahwa dengan memberikan informasi tersebut maka akan dapat menunjukkan bahwa kondisi perusahaan dalam keadaan baik sehingga akan meningkatkan nilai perusahaan dan menunjukkan bahwa kondisi perusahaan mempunyai nilai lebih keungggulan kompetitif dari perusahaan. 
Saham merupakan salah satu surat berharga yang diperdagangkan dipasar modal yang bersifat kepemilikan. Hermuningsih (2012:78), saham dapat didefinisikan sebagai bukti penyertaan atau pemilikan individu maupun institusi dalam suatu perusahaan. Seorang investor yang memutuskan untuk membeli saham maka investor menjadi pemilik atau pemegang saham perusahaan yang bersangkutan.

Saham adalah tanda bukti penyertaan kepemilikian modal/dana pada suatu perusahaan; kertas yang tercantum dengan jelas nilai nominal, namaperusahaan, disertai dengan hak dan kewajiban yang dijelaskan kepada setiap pemegangnya; persediaan yang siap untuk dijual (Fahmi, 2012:85).

Fahmi (2012:86), menyatakan dalam pasar modal ada dua jenis saham yang paling umum dikenal oleh publik, yaitu saham biasa (common stock) dan saham istimewa (preferred stock).

Current Ratio adalah rasio yang paling umum digunakan untuk mengukur solvabilitas perusahaan dari kewajiban jangka pendeknya, pada rasio ini juga dapat menunjukan perbandingan antara aset lancar dengan kewajiban lancar dan rasio ini juga dapat merepresentasikan kemampuan perusahaan untuk memenuhi kewajiban jangka pendeknya dengan aset lancar yang tersedia.

Current Ratio yang rendah menunjukkan risiko, sedangkan Current Ratio yang tinggi menunjukkan adanya kelebihan aktiva lancar, yang akan mempunyai pengaruh yang tidak baik terhadap kinerja perusahaan. Aktiva lancar secara umum menghasilkan return yang lebih rendah dibandingkan dengan aktiva tetap. 
Debt to equity ratio mengukur kemampuan perusahaan memenuhi kewajiban-kewajiban jangka panjangnya. Perusahaan yang tidak solvabel adalah perusahaan yang total hutangnya lebih besar dibandingkan total asset dan modalnya. Debt to Equity Ratio ini mengukur likuiditas jangka panjang perusahaan dan dengan demikian memfokuskan pada sisi kanan neraca.

Khalid (2012) menyatakan Debt to Equity Ratio merepresentasikan perbandingan antara kewajiban perusahaan dengan modal perusahaan, semakin tinggi Debt to Equity Ratio menunjukan bahwa semakin besarnya proporsi hutang dalam modal perusahaan yang mana akan menyebabkan resiko investasi yang lebih tinggi.

Berdasarkan study literasi dan terdapatnya fenomena empiris terkait berfluktuasinya harga saham perusahaan pharmacy pada periode 2014 - 2016. dan terdapatnya research gap pada penelitian terdahulu, maka dapat dibentuk rumusan masalah selayaknya berikut: (1) Apakah current ratio berpengaruh signifikan pada harga saham; (2) Apakah debt to equity ratio berpengaruh signifikan pada harga saham; (3) Apakah return on asset berpengaruh signifikan pada harga saham; (4) Apakah price earning ratio berpengaruh signifikan terhadap harga saham.

Current ratio merupakan cara untuk mengukur tingkat likuiditas perusahaan atau kemampuan perusahaan dalam memenuhi kewajiban jangka pendek dengan aset lancar yang tersedia. Kewajiban jangka pendek yang dimaksud seperti membayar biaya operasional, membayar hutang jangka pendek. perusahaan dikatakan likuid apabila posisi dana lancar yang tersedia lebih banyak dari utang lancar perusahaan Wiagustini (2014:76). 
Return on Asset atau disebut juga rentabilitas ekonomi ialah laba usaha dengan modal sendiri dan modal asing yang dipergunakan untuk menghasilkan laba tersebut dan dinyatakan dalam persentase (Riyanto, 2001:36). Rentabilitas ekonomi sering pula dimaksudkan sebagai kemampuan suatu perusahaan dengan seluruh modal yang bekerja di dalamnya untuk menghasilkan laba dikarenakan pengertian rentabilitas sering digunakan untuk mengukur efisiensi penggunaan modal di dalam suatu perusahaan.

Price Earning Ratio melihat harga saham relatif terhadap earning-nya. Perusahaan yang diharapkan akan tumbuh tinggi (mempunyai prospek yang baik) mempunyai Price Earning Ratio yang tinggi, sebaliknya perusahaan yang diharapkan mempunyai pertumbuhan rendah akan mempunyai Price Earning Ratio yang rendah. Price Earning Ratio merupakan rasio yang menggambarkan apresiasi pasar terhadap kemampuan perusahaan dalam menghasilkan laba dibandingkan harga sahamnya.

Penelitian ini menggunakan Current Ratio sebagai proksi dari Current Ratio karena ingin mengetahui kemampuan perusahaan memenuhi kewajiban jangka pendeknya melaluireturn saham. Perusahaan dalam operasionalnya memperoleh laba yang optimal maka akan semakin lancar pembiayaan dan pendanaan perusahaan tersebut, begitu juga sebaliknya. Hasil ini di dukung oleh penelitian yang dilakukan Ulupui (2007) dan Prince (2014) yang menyatakan bahwa Current Ratio berpengaruh signifikan terhadap harga saham, sedangkan penelitian yang dilakukan oleh Wijaya (2010) dan Pinkan (2013) yang 
menyimpulkan bahwa Current Ratio tidak memiliki pengaruh signifikan terhadap harga saham.

Kuswara (2012) dalam penelitiannya mengemukakan bahwa terdapatnya pengaruh positif dan signifikan dari Current Ratio pada harga saham perusahaan, hal ini disebabkan karena semakin tingginya Current Ratio perusahaan menunjukan semakin tinggi pula kemampuan perusahaan untuk menyelesaikan kewajibannya sehingga para investor merasa aman untuk menanamkan modalnya ke perusahaan tersebut hal ini akan meningkatkan harga saham perusahaan yang memiliki Current Ratio yang tinggi.

$\mathrm{H}_{1}$ : Current ratio berpengaruh positif signifikan terhadap harga saham

Debt to equity ratio akan memengaruhi harga saham karena DER dapat mengukur kemampuan perusahaan dalam memenuhi kewajiban hutang. Harga saham perusahaan akan maksimu apabila perusahaan dapat memperkecil biaya penggunaan berbagai macam sumber dana. Oleh karena itu, perusahaan harus mengkolaborasikan antara modal sendiri dengan sumber dana dari luar yang akan menurunkan biaya modal perusahaan menjadi proporsi yang paling tepat, yang kemudian akan meningkatkan harga saham perusahan, Martono dan Harjito (2007:300). Pemenuhan kebutuhan dana untuk investasi, perusahaan akan memadukan sumber dana permanen yang digunakan perusahaan dengan cara yang dapat memaksimumkan harga saham perusahaan. Ukuran dari bauran pendanaan yang digunakan perusahaan adalah Debt to Equity Ratio. Debt to Equity Ratio akan mempengaruhi harga saham karena rasio ini digunakan untuk mengukur kemampuan perusahaan dalam menutupi sebagian atau seluruh hutang- hutangnya 
baik jangka panjang maupun jangka pendek yang berasal dari modal sendiri. Harga saham perusahaan dapat dimaksimumkan, jika perusahaan dapat meminumkan biaya penggunaan berbagai macam sumber dana. Perusahaan perlu mengkombinasikan antara modal sendiri dengan sumber dana yang dapat meminimalkan biaya modal perusahaan dalam proporsi yang paling tepat, sehingga harga saham perusahaan dapat meningkat, Martono dan Harjito (2007:300).

$\mathrm{H}_{2}$ : Debt to equity ratio berpengaruh negatif signifikan terhadap harga saham.

Nirmala et al (2011) menemukan pengaruh ROA yang positif signifikan pada semakin tinggi keuntungan yang dapat di hasilkan perusahaan berdasarkan aktivitas nya maka semakin banyak keuntungan yang di berikan pada pemegang saham dan akan meningkatkan harga perusahaan. Indikator Return on Asset merupakan salah satu indikator keuangan yang sering digunakan dalam menilai kinerja perusahaan. Dengan meningkatnya Return on Asset berarti kinerja perusahaan semakin baik dan sebagai dampaknya harga saham perusahaan semakin meningkat. Dengan meningkatnya harga saham, maka harga saham perusahaan yang bersangkutan juga meningkat. Teori tersebut juga konsisten dengan hasil penelitian yang dilakukan oleh Patel (2014) yang menyatakan bahwa Return on Asset berpengaruh positif dan signifikan terhadap harga saham. Hasil penelitian yang sama dilakukan oleh Susilawati (2012) dan Nurmalasari (2009), menemukan bahwa Return on Asset memiliki pengaruh yang positif dan signifikan terhadap harga saham. Hal ini berarti semakin tinggi Return on Asset suatu perusahaan, maka semakin tinggi pula harga saham yang dihasilkan.

$\mathrm{H}_{3}$ : Return on asset berpengaruh positif signifikan terhadap harga saham 
Price Earing Ratio menunjukan seberapa besar para investor bersedia dibayar untuk setiap keuntungan yang dilaporkan perusahaan sehingga merupakan salah satu alat untuk mengukur kinerja perusahaan. Sanjeet (2011) menarik kesimpulan bahwa Price Earning Ratio mempunyai pengaruh positif dan signifikan terhadap harga saham pada perusahaan. Price Earning Ratio, yaitu rasio yang menunjukkan perbandingan antara harga saham dipasar atau harga perdana yang ditawarkan dibandingkan dengan pendapat yang diterima. Rasio penilaian pasar yang digunakan dalam penelitian ini adalah Price Earning Ratio. Price Earning Ratio digunakan oleh para investor untuk memprediksi kemampuan perusahaan dalam menghasilkan laba dimasa yang akan datang. Perusahaan yang memiki Price Earning Ratio yang tinggi biasanya memiliki peluang tingkat pertumbuhan yang tinggi, begitu juga sebaliknya perusahaan yang memiliki Price Earning Ratio yang rendah biasanya memiliki tingkat pertumbuhan yang rendah. $\mathrm{H}_{4}$ : Price earning ratio berpengaruh positif signifikan terhadap harga saham

\section{METODE PENELITIAN}

Pendekatan yang digunakan dalam penelitian ini adalah pendekatan kuantitatif asosiatif, yaitu untuk mengetahui pengaruh CR, DER ROA, dan PER terhadap harga saham perusahaan. Objek penelitian ini adalah Pengaruh CR, DER, ROA, PER terhadap harga saham pada perusahaan pharmacy di Bursa Efek Indonesia.

Penelitian ini dilakukan pada perusahaan Pharmacy yang terdaftar di Bursa Efek Indonesia yang dapat diakses di www.idx.co.id. Data yang didapatkan 
berbentuk Indonesian Capital Market Dictionary (ICMD) dan data historis lainya yang berkaitan dengan data-data yang diperlukan dalam penelitian ini.

Populasi penelitian inimenggunakan semua perusahaan Pharmacy di Bursa Efek Indonesia. Penelitian ini menggunakan 8 sampel perusahaan Pharmacy yang terdaftar di Bursa Efek Indonesia dengan menggunakan teknik penentuan sampel purposive sampling, dimana tujuan menggunakan purposive sampling ialah untuk mendapatkan sampel yang representatif sesuai dengan kriteria yang ditentukan peneliti. Adapun kriteria penentuan sampel dalam penelitian ini adalah perusahaan Pharmacy yang memiliki laba atau profit karena variabel yang digunakan merupakan alat untuk mengukur kinerja suatu perusahaan dimana perusahaan yang memiliki kinerja perusahaan yang tinggi merupakan perusahaan yang sehat dalam arti dapat memenuhi kewajibannya dan merupakan suatu keberhasilan dalam memperoleh laba/profit.

Pengujian terhadap hipotesis yang diajukan dilakukan dengan metode regresi linier berganda. Dalam penelitian ini akan digunakan alat bantu berupa software statistik yakni SPSS 13.0. Analisis regresi linier berganda digunakan untuk menguji pengaruh dengan menggunakan variabel dependen (terikat) dan variabel independen (bebas) (Pratama, 2014). Adapun persamaan regresi berganda dalam penelitian ini adalah sebagai berikut:

$$
\mathrm{Y}=\alpha+\beta 1 \mathrm{X}_{1}+\beta_{2} \mathrm{X}_{2}+\beta_{3} \mathrm{X}_{3}+\beta_{4} \mathrm{X}_{4}+\mathrm{e}
$$

Keterangan:

$\mathrm{Y}=$ Harga Saham $\alpha=$ Konstanta

$\beta_{1}-\beta_{4}=$ Koefisien regresi variabel independen

$\mathrm{X}_{1} \quad=$ Current Ratio

$\mathrm{X}_{2} \quad=$ Debt to Equity Ratio

$\mathrm{X}_{3} \quad=$ Return On Asset

$\mathrm{X}_{4} \quad=$ Price Earning Ratio 
Uji hipotesis yang digunakan antara lain; uji kelayakan model (F-test), uji parsial (t-test) dan uji koefisien determinasi $\left(\mathrm{R}^{2}\right)$.

\section{HASIL DAN PEMBAHASAN}

Pengaruh Current Ratio, Debt to Equity Ratio, Return on Asset, dan Price Earning Ratio terhadap Harga Saham pada perusahaan Pharmacy di Bursa Efek Indonesia periode tahun 2014 hingga 2016. Berdasarkan laporan keuangan tahunan, diperoleh hasil analisis statistik dekriptif sebagai berikut.

Tabel 1.

Hasil Analisis Statistik Deskriptif

\begin{tabular}{lrllll}
\hline & N & Minimum & Maximum & Mean & Std. Deviation \\
\hline ROA (\%) & 24 & -126.00 & 2532.00 & 1006.7500 & 733.34684 \\
DER (\%) & 24 & 8.00 & 159.00 & 47.9583 & 37.25643 \\
CR (\%) & 24 & 121.80 & 1025.42 & 26251.0870 & 24114.29004 \\
PER (x) & 24 & -2313.00 & 35775.00 & 4254.6250 & 7305.97877 \\
ClosingPrice & 24 & 112.00 & 16000.00 & 2496.0417 & 3575.84996 \\
Valid N (listwise) & 24 & & & \\
\hline
\end{tabular}
Sumber: Data diolah, 2018

Tabel 1 di atas menunjukan terdapat 24 data yang di analisis yang di peroleh dari jumlah sampel sebanyak 8 perusahaan dikalikan dengan periode penelitian dari tahun 2014 hingga 2016 yaitu selama 3 tahun. Tabel tersebut juga menjelaskan nilai minimum, nilai maksimum, nilai rata-rata dan standar deviasi dari masing-masing variabel yang digunakan dalam penelitian ini.

Vriabel Current Ratio nilai minimumnya adalah 121,8 yang terjadi pada perusahaan PT. Indofarma Tbk pada tahun 2016, nilai maximum dari variabel Current Ratio adalas sebesar 1025,42 yang terdapat pada perusahaan PT. Industri Jamu dan Farmasi Sido Muncul Tbk pada tahun 2014. Nilai rata-rata dari 
variabel Current Ratio sebesar 2.6251 hal tersebut menunjukan bahwa rata-rata aktiva lancar perusahaan yang termasuk dalam sampel adalah sebesar 2.6251 kali lebih besar dari kewajiban lancar perusahaan. Artinya, banyak perusahaan yang memiliki aktiva lancar tersedia yang lebih besar dari kewajiban lancar yang harus dipenuhi perusahaan. Standar deviasi Current Ratio dari tabel di atas sebesar 2.4114 angka tersebut menunjukan bahwa penyimpangan distribusi variabel Current Ratio pada perusahaan Farmasi dari rata-ratanya sebesar 2.4114.

Rasio Debt to Equity Ratio minimum adalah sebesar 0.08 yang terdapat pada perusahaan PT. Industri Jamu dan Farmasi Sido Muncul Tbk pada tahun 2014 dan Rasio Debt to Equity Ratio maximum adalah sebesar 1.59 yang terdapat pada perusahaan PT. Indofarma Tbk pada tahun 2016. Nilai rata-rata rasio Debt to Equity Ratio sebesar 0,47 menunjukan bahwa rata-rata utang perusahaan yang termasuk dalam sampel adalah sebesar 0,47 kali dibandingkan dengan modal sendiri yang di miliki perusahaan, artinya banyak perusahaan yang menggunakan pendanaan dari hutang jangka panjang dibandingkan dengan menggunakan modal sendiri dalam pendanaan perusahaan. Standar deviasi rasio Debt to Equity Ratio sebesar 0,37 menunjukan penyimpangan distribusi nilai variabel Debt to Equity Ratio pada perusahaan Farmasi dari rata-ratanya sebesar 0,37.

Rasio Return on Asset minimum berdasarkan tabel diatas adalah sebesar 1,26 yang terdapat pada perusahaan PT. Indofarma Tbk pada tahun 2016 dan rasio Return on Asset maximum adalah sebesar 25.32 yang terdapat pada perusahaan PT. Merck Tbk pada tahun 2014. Nilai rata-rata rasio Return on Asset adalah sebesar 10.06 yang artinya perusahaan mampu menghasilkan laba bersih 100.6 persen dari 
keseluruhan modal yang dimiliki perusahaan. Standar deviasi rasio Return on Asset adalah sebesar 7,3 angka tersebut menunjukan bahwa penyimpangan distribusi nilai variabel Return on Asset pada perusahaan Farmasi dari rata-ratanya adalah sebesar $7,3$.

Rasio Price Earning Ratio minimum adalah sebesar -23,13 yang terdapat pada perusahaan PT. Indofarma Tbk pada tahun 2014 dan nilai Price Earning Ratio maximum adalah sebesar 357,75 yang terdapat pada perusahaan PT. Indofarma Tbk pada tahun 2016. Nilai rata-rata Price Earning Ratio adalah sebesar 42.54 menunjukan bahwa pendapatan setelah pajak perusahaan 42.54 lebih besar dari jumlah lembar saham yang beredar. Standar deviasi dari Price Earning Ratio adalah sebesar 73,05 angka tersebut menunjukan penyimpangan distribusi nilai variable Price Earning Ratio pada perusahaan Farmasi dari rata- ratanya adalah sebesar 73,05 .

Harga Saham Perusahaan Farmasi minimum dapat dilihat dari tabel adalah sebesar 112 yang terdapat pada perusahaan PT. Pyridam Farma Tbk. pada tahun 2015 dan harga saham maximum adalah sebesar 16.000 yang terdapat pada perusahaan PT. Merck Tbk. Nilai rata-rata harga saham adalah sebesar 2496.04 menunjukan bahwa rata-rata harga saham penutupan perusahaan Farmasi pada tiap tahunya adalah sebesar 2496.04. Standar deviasi harga saham adalah sebesar 3575 menunjukan penyimpangan harga saham perusahaan Farmasi dari rata-rata harga saham.

Uji Normalitas dilakukan dengan menggunakan uji Kolmogorov-Smirnov (K-S). Hasil uji dinyatakan memiliki distrbusi normal Asymp. Sig (2-tailed) 
melebihi nilai $(\alpha)=0.05$ atau 5\%. Tabel 1 di bawah menunjukan variabel CR, DER, ROA, dan PER memiliki distribusi normal. Terlihati dari nilai asymp. Sig (2-tailed) sebesar 0.628 yang melebihi tingkat signifikansi (0.05). sekaligus menunjukan bahwa model penelitian ini memiliki distribusi normal.

Tabel 2.

Hasil Uji Normalitas

\begin{tabular}{llr}
\hline \multicolumn{2}{c}{ Unstandardized Residual } & \\
\hline $\mathrm{N}$ & & 23 \\
Normal Paramaters & Mean & 0,000 \\
Most Extreme & Std.Deviation & 360,49216198 \\
Differences & Absolute & 0,158 \\
Kolmogorov-Smirnov & Positive & 0,137 \\
Z & Negative & $-0,156$ \\
Asymp.Sig (2-tailed) & & 0,750 \\
& & 0,628 \\
\hline Sumber:
\end{tabular}

Sumber: Data diolah, 2018

Tabel 3.

Hasil Uji Autokorelasi (Model Summary)

\begin{tabular}{llllll}
\hline Model & R & R Square & $\begin{array}{l}\text { Adjusted R } \\
\text { Square }\end{array}$ & $\begin{array}{l}\text { Std. Error of } \\
\text { the Estimate }\end{array}$ & $\begin{array}{l}\text { Durbin } \\
\text { Watson }\end{array}$ \\
\hline 1 & $0,896^{\mathrm{a}}$ & 0,803 & 0,759 & 398,539 & 2,127 \\
\hline Sumber: Data diolah, 2018 & & & &
\end{tabular}

Terlihat nilai Durbin - Watson 2,127, jumlah sampel 24 dengan 4 variabel bebas , dengan nilai dU $=1.775$ dan $4-\mathrm{dU}=2,224$, terlihat nilai Durbin - Watson pada table di atas berada di antara dU dan 4-dU yang yang sekaligus menunjukan tidak terdapatnya gejala auto korelasi.

Tabel 4.

Durbin - Watson

\begin{tabular}{lll}
\hline Batas bawah & Durbin - Watson & Batas atas \\
\hline$(\mathrm{dU})=1,775$ & 2,127 & $(4-\mathrm{dU})=2,224$ \\
\hline Sumber: Data diolah, 2018 &
\end{tabular}


Tabel 5.

Hasil Uji Multikolinieritas

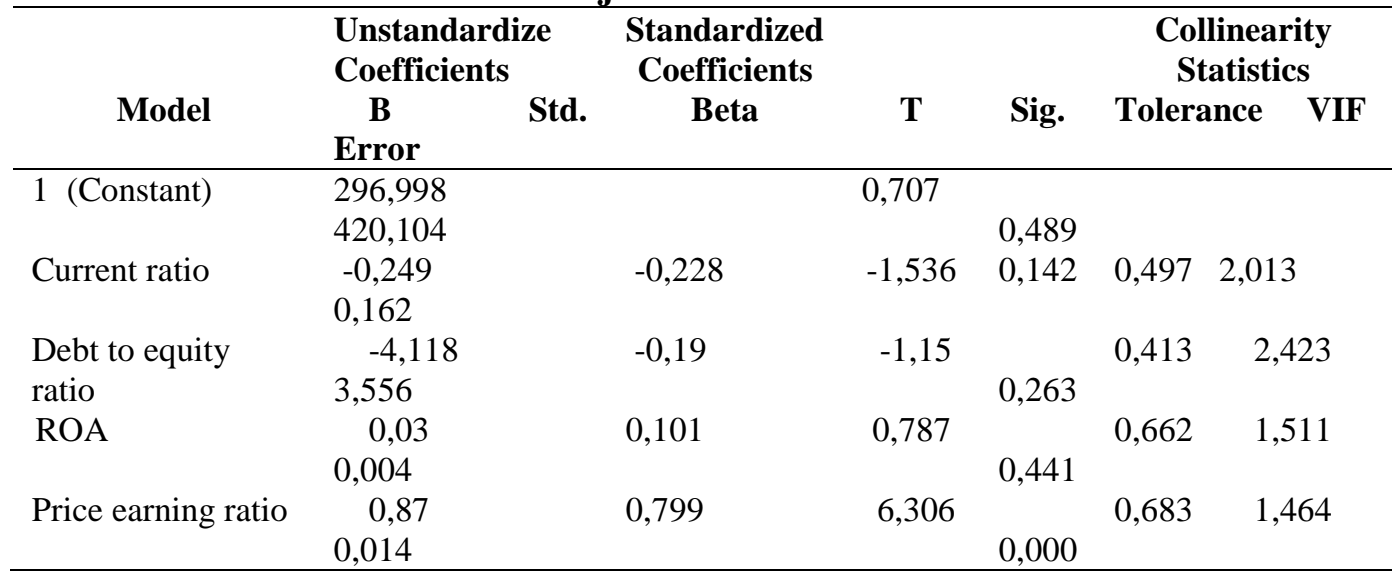

Sumber: Data diolah, 2018

Terlihat nilai tolerance untuk variabel CR, DER, ROA, dan PER secara berturut-turut sebesar, $0.497,0.413,0.662$, dan 0.683 dan terlihat tidak terdapat nilai tolerance yang lebih kecil dari 0,10 , untuk nilai VIF Variabel independent seluruhanya sebesar, $2.013,2.423,1.511$, dan1.464 dapat dilihat tidak terdapatnya nilai VIF yang lebih kecil dari 10, makan tidak terdapat gejala multikolinearitas.

Pengujian Heteroskedastisitas dapat dilakukan dengan melakukan uji Glejser, model regresi yang bebas dari gejala Heteroskedastisitas adalah model dengan signifikansi variabel independent terhadap nilai absolut residual statistik di atas $\alpha=$ 0.05, dan pada penelitian ini tidak terdapat gejala heteroskedastisitas.

Tabel 6.

Hasil Analisis Regresi Linier Berganda

\begin{tabular}{lccccc}
\hline \multicolumn{7}{c}{$\begin{array}{c}\text { Unstandardized } \\
\text { Coefficients }\end{array}$} & $\begin{array}{c}\text { Standardized } \\
\text { Coefficients }\end{array}$ & & \\
Model & B & Std. Error & Beta & T & Sig. \\
\hline 1 (Constant) & 296,998 & 420,104 & & 0,707 & 0,489 \\
Current ratio & $-0,249$ & 0,162 & $-0,228$ & $-1,536$ & 0,142 \\
Debt to equity ratio & $-4,118$ & 3,556 & $-0,19$ & $-1,15$ & 0,263 \\
ROA & 0,03 & 0,004 & 0,101 & 0,787 & 0,441 \\
Price earning ratio & 0,87 & 0,014 & 0,799 & 6,306 & 0,000 \\
\hline Sumber: Data diolah, 2018 & & & & &
\end{tabular}


Persamaan linear berganda yang didapat dari table di atas adalah sebagai berikut:

$$
\hat{Y}=2803.019-811.929 X_{1}+91.101 X_{2}+66.676 X_{3}+9.593 X_{4} U i
$$

Nilai koefisien regresi menunjukkan bahwa Current Ratio mempengaruhi Harga Saham sebesar 0.228 dengan arah negatif sebesar -0,249. tingkat signifikansi menunjukan angka 0.142 dimana lebih besar dari nilai $\alpha 0.05$. Berdasarkan hasil uji tersebut maka Current Ratio tidak berpengaruh signifikan terhadap Harga Saham Perusahaan Farmasi di BEI periode tahun 2014-2016, hal tersebut menunjukan bahwa penelitian tidak mendukung penelitian yang dilakukan oleh Mahardika (2011) dan Kuswara (2012) akan tetapi mendukung penelitian dari Pradipta (2012) dalam penelitiannya yang menemukan bahwa Current Ratio memiliki pengaruh yang negatif terhadap harga saham perusahaan, hal ini disebabkan apabila perusahaan dengan Current Ratio tinggi menunjukkan adanya kelebihan aktiva lancar, yang akan mempunyai pengaruh tidak baik terhadap kinerja perusahaan. Current Ratio yang terlalu tinggi mengindikasikan terdapatnya idle fund (dana menganggur) yang tinggi pula, sehingga mencerminkan perusahaan kurang mampudalam mengoperasionalkan asset lancarnya sehingga dapat menimbulkan opportunity lost (kondisi merugi).

Nilai koefisien regresi menunjukkan bahwa Debt to Equity Ratio mempengaruhi Harga Saham sebesar 0.19 dengan arah negatif sebesar - 4,118, tingkat signifikansi menunjukan angka 0.263 dimana lebih besar dari nilai $\alpha 0.05$. Berdasarkan hasil uji tersebut maka Debt to Equity Ratio tidak berpengaruh signifikan dengan arah negatif terhadap Harga Saham Perusahaan Farmasi di BEI 
periode tahun 2014-2016, hal tersebut menunjukan bahwa penelitian mendukung penelitian yang dilakukan oleh Nirmala et al.(2011) dan Hatta dan Dwiyanto (2012) akan tetapi tidak mendukung penelitian dari Pradipta (2012) yang menemukan adanya pengaruh Debt to Equity Ratio yang positif pada harga saham perusahaan Farmasi Indonesia yang terdaftar di dalam LQ45 tahun 2009-2011 karena rasio Debt to Equity Ratio masih menjadi pertimbangan bagi para investor untuk menanamkan modalnya pada perusahaan-perusahaan tertentu. Perusahaan dengan Debt to Equity Ratio yang tinggi menunjukkan bahwa semakin besarnya proporsi hutang yang dimiliki perusahaan tersebut, perusahaan akan lebih percaya diri menggunakan pendanaan dari luar perusahaan sehingga perusahaan akan berfokus pada penyelesaian kewajiban (membayar utang) bukan memberikan keuntungan kepada pemegang saham.

Nilai koefisien regresi menunjukkan bahwa Return on Asset mempengaruhi Harga Saham sebesar 0.101 dengan arah positif sebesar 0,03 tingkat signifikansi menunjukan angka 0.441 dimana lebih besar dari nilai $\alpha 0.05$. Berdasarkan hasil uji tersebut maka Return on Asset tidak berpengaruh signifikan dengan arah positif terhadap Harga Saham Perusahaan Farmasi di BEI periode tahun 2014-2016, hal tersebut menunjukan bahwa penelitian tidak mendukung penelitian yang dilakukan oleh Pradipta (2012) akan tetapi mendukung hasil penelitian dari Wang et al.(2013) pada 60 perusahaan yang terdaftar di bursa saham Shanghai tahun 2011 menemukan adanya pengaruh Return on Asset yang positif pada harga saham perusahaan karena Return on Asset perusahaan selalu dapat menggambarkan harga saham perusahaan di masa yang akan datang. Nirmala et al.(2011) Menyatakan 
semakin tingginya keuntungan yang dapat di hasilkan oleh perusahaan maka kemampuan perusahaan untuk beroperasi akan menjadi lebih baik dan hal tersebut dapat menstimulasi terjadinya peningkatan harga saham perusahaan di pasar saham, hal tersebut dapat di artikan bahwa Return on Asset memiliki pengaruh yang positif pada harga saham perusahaan.

Nilai koefisien regresi menunjukkan bahwa Price Earning Ratio mempengaruhi Harga Saham sebesar 0.799 dengan arah positif sebesar 0,87, tingkat signifikansi menunjukan angka 0.00 dimana lebih kecil dari nilai $\alpha 0.05$. Berdasarkan hasil uji tersebut maka Price Earning Ratio berpengaruh positif dan signifikan terhadap Harga Saham Perusahaan Farmasi di BEI periode tahun 2014-2016. Hasil tersebut tidak mendukung penelitian yang dilakukan oleh Julia (2008), akan tetapi mendukung hasil penelitian dari Malintan (2012) yang menyatakan bahwa semakin tinggi Price Earning Ratio maka harga saham dinilai semakin tinggi oleh investor, sehingga Price Earning Ratio yang semakin tinggi juga menunjukkan semakin mahal saham tersebut terhadap pendapatannya. Penelitian Sugiartingingsih (2004) juga menemukan hasil bahwa Price Earning Ratio secara signifikan berpengaruh positif terhadap harga saham. Semakin tinggi Price Earning Ratio suatu perusahaan akan meningkatkan harga saham perusahaan tersebut.

Penelitian ini membahas mengenai pengaruh variabel Current Ratio, Debt to Equity Ratio, Return on Asset, dan Price Earning Ratio pada perusahaan Pharmacy di Bursa Efek Indonesia periode 2014-2016. Hasil uji dalam penelitian ini bahwa Price Earning Ratio berpengaruh signifikan terhadap harga saham dan Current 
Ratio, Debt to Equity Ratio, Return on Asset tidak berpengaruh signifikan dalam harga saham.

Variabel pertama adalah Current Ratio memiliki pengaruh negatif tidak signifikan terhadap harga saham pada perusahaan farmasi. Current Ratio merupakan kemampuan perusahaan untuk memenuhi kewajiban finansial jangka pendek dengan dana lancar. Perusahaan dengan Current Ratio yang tinggi menunjukkan adanya kelebihan aktiva lancar yang akan mempunyai pengaruh tidak baik terhadap kinerja perusahaan.

Variabel kedua adalah Debt to Equity Ratio memiliki pengaruh negatif tidak signifikan terhadap harga saham pada perusahaan farmasi. Debt to Equity Ratio mencerminkan kemampuan perusahaan membiayai usaha dengan pinjaman yang disediakan pemegang saham. Perusahaan dengan Debt to Equity Ratio tinggi akan lebih fokus untuk membayar utang bukan memberikan keuntungan kepada pemegang saham, karena semakin tinggi Debt to Equity Ratio maka semakin besar juga proporsi utang yang dimiliki perusahaan.

Variabel ketiga adalah Return on Asset memiliki pengaruh positif tidak signifikan terhadap harga saham pada perusahaan farmasi. Return on Asset merupakan kemampuan perusahaan dalam menghasilkan laba. Perusahaan dengan Return on Asset tinggi memiliki kinerja perusahaan yang semakin baik dan menunjukkan semakin efektif dalam memanfaatkan aktiva untuk menghasilkan laba.

Variabel keempat adalah Price Earning Ratio memiliki pengaruh positif signifikan terhadap harga saham pada perusahaan farmasi. Price Earning Ratio 
merupakan suatu alat yang digunakan investor untuk memprediksi kemampuan perusahaan dalam menghasilkan laba dimasa datang. Perusahaan dengan Price Earning Ratio yang tinggi akan mermiliki peluang tingkat pertumbuhan yang tinggi pula.

\section{SIMPULAN DAN SARAN}

Berdasarkan pembahasan yang telah di uraikan pada bab sebelumnya dapat di peroleh simpulan bahwa Current Ratio tidak berpengaruh signifikan terhadap Harga Saham Perusahaan Farmasi di BEI Periode 2014-2016. Hal ini berarti dalam berinvestasi investor tidak memperhatikan likuiditas yang diukur Current Ratio pada perusahaan Pharmacy periode 2014-2016.

Debt to Equity Ratio tidak berpengaruh signifikan terhadap Harga Saham Perusahaan Farmasi di BEI Periode 2014-2016. Hal ini berarti dalam berinvestasi investor tidak memperhatikan adanya sumber dana yang tinggi yang diukur menggunakan Debt to Equity Ratio pada perusahaan Pharmacy periode 2014-2016.

Return on Asset tidak berpengaruh signifikan terhadap Harga Saham Perusahaan Farmasi di BEI Periode 2014-2016. Hal ini berarti bahwa investor tidak memperhatikan aktiva yang berasal dari modal sendiri yang diukur menggunakan Return on Asset pada perusahan Pharmacy periode 2014-2016.

Price Earning Ratio berpengaruh positif dan signifikan terhadap Harga Saham Perusahaan Farmasi di BEI Periode 2014-2016. Hal ini berarti bahwa investor memperhatikan Price Earning Ratio karena investor mengharapkan adanya pertumbuhan perusahaan yang lebih tinggi pada perusahan Pharmacy 
periode 2014-2016.

Berdasarkan atas simpulan dan hasil analisis, dapat dikemukakan beberapa saran sebagai berikut bagi peneliti selanjutnya, alangkah baiknya memperhatikan bahwa secara parsial, hanya variabel Price Earning Ratio yang berpengaruh secara signifikan terhadap Harga Saham perusahaan Farmasi di BEI perode 2014- 2016, peneliti selanjutnya juga disarankan untuk mempertimbangkan faktor-faktor lain yang yang dapat mempengaruhi Harga Saham perusahaan selain menggunakan rasio keuangan Current Ratio, Debt to Equity Ratio, Return nn Asset dan Price Earning Ratio. Bagi peneliti selanjutnya, disarankan untuk menggunakan objek yang lebih luas, tidak hanya perusahaan di sub sektor Farmasi tetapi juga di sektor lainnya, menambah periode penelitian yang lebih panjang sehingga hasilnya lebih dapat digeneralisasi, menambahkan atau mengganti variabel baik faktor internal maupun eksternal perusahaan yang lebih mempengaruhi Harga Saham perusahaan.

Bagi perusahaan, diharapkan peneletian ini dapat menjadikan motivasi untuk meningkatkan harga saham dengan indikasi kinerja perusahaan dan memperhatikan Nilai PER dalam menentukan Investasi karena PER berpengaruh positif signifikan terhadap harga saham sehingga dapat tercemin dalam laporan keuangan yang disusun serta sebagai dasar pengambilan keputusan menyangkut rasio kinerja keuangan terhadap investasi saham.

Bagi investor maupun kreditur, diharapkan penelitian ini dapat dijadikan dasar dalam penilaian kinerja manajemen yang menjadi awal dalam proses transaksi dan proses pengambilan keputusan investasi. 


\section{REFRENSI}

Alkhatib, Khalid. (2012). The Determinants of Debt to Equity Ratio of Listed Companies,International Journal of Business and Social Science. Vol. 3 no. 24 Special Issue

Brigham, Eugene Fdan Houston, Joel F. (2006).Dasar-dasar Manajemen Keuangan, Edisi 10. Jakarta: Salemba Empat.

Clarke, A. Kevin. (2005). The Phantom Menace: Omitted Variable Bias in Econometric Research. Conflict Management and Peace Science. 2(2).pp341-352

Darmadji, Tjiptono. (2012). Pasar Modal Di Indonesia: Pendekatan Tanya Jawab, Edisi 3, Jakarta: Salemba Empat.

Ghozali, Imam. (2012). Aplikasi Analisis Multivariate dengan Program SPSS, Badan Penerbit Universitas Diponegoro, Semarang.

Harahap, Sofyan Syafri. (2010). Analisis Kritis atas Laporan Keuangan, Jakarta: PT Raja Grafindo Persada.

Hartono, Jogiyanto. (2013). Teori Portofolio dan Analisis Investasi. Edisi Kedelapan. Yogyakarta: BPFE.

Hermuningsih, Sri. (2012). Pengantar Pasar Modal Indonesia. Yogyakarta: UPP STIM YKPN

Hunjra, Ahmed Imran and Ijaz, Muhammad Shahzad and Chani, Muhammad Irfan and Hassan, Sabih ul and Mustafa, Umer, (2014). Impact of Dividend policy, Price earning ratio, Return on Equity, Profit after tax on Stock Prices. Published in: International Journal Of Economics and Empricial Research, Vol.2, No.3: 109-115

Husnan, Suad. (2009). Dasar-dasar Teori Portofolio Dan Analisis Sekuritas. Edisi Keempat. Yogyakarta: UPP STIM YKPN.

Haque, Samina and Murtaza Faruquee. (2013), Impact of Fundamental Factors on Stock Price: A Case Based Approach on Pharmaceutical Companies Listed with Dhaka Stock Exchange, International Journal of Business and Management Invention, 2(9), pp.34-41.

Jauharia,Atika dan Bambang Sugeng. (2012). The Company Fundamental Factors And Systematic Risk in Increasing Stock Price.Journal of Economics, Business and Accountancy Ventura, 15(2), pp: 245 - 256 
Khan, Ather Azim dan Kanwal IqbalKhan. (2011). Dividend Policy and Stock Prices - A Case of KSE- 100 Index Companies. Journal of Commerce, Vol. 321. Pp:1-25

Komala, Lieviea Angela Pinkan dan Paskah Ika Nugroho. (2013). The Effect of Profitability Ratio, Liquidity, and Debt Towards Investment Return, Journal of Business and Economic, Vol.4, no.11, pp.1176-1186

Martono, dan D Agus Harjito. (2007). Manajemen Keuangan. Cetakan keempat. Yogyakarta: EKONISIA

Nirmala, P. S., P. S. Sanju, dan M. Ramachandran. (2011). Determinants Of Share Prices In India. Journal of Emerging Trends in Economics and Management Sciences (JETEMS), Vol. 2, no. 2. pp. 124-130.

Omete, Francis L. (2013). The Effects of Earnings Per Share, Dividend Per Share, and Price To Earnings Ratio on Share Prices: The Case of Firms Listed at Nairobi Securities Exchanges. International Journal Of Innovative Research and Studies. 2 (9), pp: 30-50

Pasaribu, Rowland Bismark Fernando. (2008). Pengaruh Variabel Fundamental terhadap Harga Saham Perusahaan Go Public di Bursa Efek Indonesia (BEI) periode 2003-2006. Jurnal Ekonomi dan Bisnis, 2 (2), pp: 101-113

Patel, J. B, October. (2014)..Impact of Debt to Equity Ratio on Profitability: A Study of Sabar Dairy,International Multidisciplinary Research Journal, Vol.1, Issue 3, ISSN: 2349-7637

Perwira, Adi Baskara \& Darsono. (2015). Analisis Pengaruh Manajemen Laba dan Asimetri Informasi Terhadap Biaya Modal Ekuitas. Diponegoro Journal of Accounting, 4 (4): 1-11, ISSN (Online): 2337-3806..

Pradipta, Gilang. (2012).The Influence Of Financial Ratio Towards Stock Price (Empirical Study on Listed Companies in Indonesia Stock Exchange of LQ45 in 2009-2011). Journal of Financial and Accounting, 6(!), pp: 1-9

Sharma, Sanjeet, (2011). Determinans Of Equity Share Prices In India. Journal of Arts, Sciences \& Commerce, 2 (4), pp: 51-60

Silviana and Rocky. (2013). Analysis of Return on Assets and Earnings per Share on the Stock Market in the Banking Companies In Bursa Efek Indonesia (Indonesia Securities Exchange), Journal of Global Business and Economics, vol. 7, no.1. pp. 119-125

Sugiyono. (2013). Metode Penelitian Pendidikan (Pendekatan Kuantitatif, Kualitatif dan $R \& D)$. Bandung: Alfa Beta.

Wang, Junjie, Gang Fu, and Chao Luo. (2013). Accounting Information and Stock Price Reaction of Listed Companies - Empirical Evidence from 60 Listed 
E-Jurnal Manajemen Unud, Vol. 8, No. 3, 2019: 1844 - 1871

Companies in Shanghai Stock Exchange. Journal of Business \& Management. 2(2), pp:11-21.

Wiagustini, Luh Putu. (2014). Dasar-dasar Manajemen Keuangan, Denpasar Udayana University Press. 